\title{
Physicochemical analysis of Lake Enriquillo in Dominican Republic
}

Gladys Rosado ${ }^{1}$, Méndez-Tejeda Rafael ${ }^{2 *}$, Diego V Rivas ${ }^{1}$, Maria I. Infante $^{1}$

${ }^{1}$ Center of Marine Biology (CIBIMA), Autonomous University of Santo Domingo, Santo Domingo, Dominican Republic

${ }^{2}$ Atmospherical Research Laboratory, University of Puerto Rico at

Carolina, Carolina, Puerto Rico

*Corresponding Author: Méndez-Tejeda Rafael: rafael.mendez@upr.edu

\section{OPEN ACCESS}

Citation: Rosado G., Rafael M.T., Rivas V.D., Infante I. M. (2016) Physicochemical analysis of Lake Enriquillo in Dominican Republic. Open Science Journal 1(3)

Received: $24^{\text {th }}$ August 2016

Accepted: $8^{\text {th }}$ November 2016

Published: $17^{\text {th }}$ November 2016

Copyright: (C) 2016 This is an open access article under the terms of the Creative Commons

Attribution License, which permits unrestricted use, distribution, and reproduction in any medium, provided the original author and source are credited.

Funding: Funds provided by FONDOCYT (2009-2012) and NASA Space Grant Consortium.

Competing Interests: The author have declared that no competing interests exists.

\section{Abstract}

The water level in Lake Enriquillo in the Dominican Republic (DR) has increased by an unprecedented amount over the last decade, inundating thousands of acres of farmland and more than a dozen villages and inflicting adverse social, environmental, and economic impacts on the nation. The Lake Enriquillo Basin (LEB), located near the towns of Independencia and Bahoruco in the southwest region of the DR, is bordered to the north by the Sierra de Neyba mountain range and to the south by the Sierra de Bahoruco mountain range. Lake Enriquillo is hypersaline and endorheic, with a water level that normally fluctuates between $40-50 \mathrm{~m}$ below sea level (BSL). However, since 2000, both Lake Enriquillo and Lake Azuei (Sumastre) in Haiti have experienced alarming water level increases, with Lake Enriquillo's water level rising to $17.2 \mathrm{~m}$ BSL This article explores the changes in some of the important physicochemical parameters - such as salinity, dissolved oxygen, temperature, and $\mathrm{pH}$ - that have occurred in the period from 1977 to 2012. The highest salinity value occurred in 2012, at a value $103.1 \%$, with an average increase of $27.06 \%$, coinciding with the lake level of $17.2 \mathrm{~m}$ BSL. Changes in these parameters have caused damage to the ecosystem and the lives of people and species that inhabit the region. 
Keywords: Physicochemical; Lake Enriquillo; Hypersaline Lake; Endorheic Lake

\section{Introduction}

Lake Enriquillo is a hypersaline and endorheic lake in the Dominican Republic (DR) that has a normal water level of about $40 \mathrm{~m}$ below sea level (BSL). However, since 2000, both Lake Enriquillo and the nearby Lake Azuei (Sumastre) in Haiti have experienced alarming increases in their water levels. In the case of the Lake Enriquillo, the water level has increased to $17.2 \mathrm{~m}$ BSL. This increase has had adverse effects on humans, vegetation, and fauna in the region (Méndez-Tejeda et al. 2016 and Comarazamy et al. 2015).

Lake Enriquillo is located between the provinces of Independencia and Bahoruco in the southwest of the country. It is bordered by the Sierra de Neyba mountain range to the north and by the Sierra de Bahoruco mountain range to the south. Both mountain ranges produce substantial amounts of water daily, feeding reservoirs, rivers, and streams. The time interval between the initial deposition of water in the mountains and when it reaches Lake Enriquillo is between one and three years. Lake Enriquillo is also bounded by the nation's border to the west, and it lies east of the Laguna de Cabral and the Yaque del Sur river (YSR) delta. A national park, Lake Enriquillo, and Cabritos Island are the main fixtures of the Enriquillo Region and form the important JaraguaBahoruco-Enriquillo Biosphere Reserve (Greer et al. 2006, Medley et al. 2007, Duquela and González 1983). The Lake Enriquillo Basin (LEB) is a closed basin that converges in a tectonic depression of $35 \times 12 \mathrm{~km}$. Surface runoff collects to form the major water sources for Lake Enriquillo. Approximately 80 spring water sources also feed the lake, with the most important being the Marias, Guayabal, Las Zufradas, Las Barias, Canal Cristobal, Rio Amada, La Cuesta, Boca Cachón, and Laguna Limón (Buck et al. 2005).

The Caribbean climate depends on several factors, including the so-called Caribbean Regulator Climate Centers (CRCCs), the North Atlantic Oscillation (NAO), the El Niño Southern Oscillation (ENSO), trade winds, and the North Atlantic Warm Water Pool, the Multidecadal Oscillation, and the behavior of the Azores anticyclone. The presence of ENSO, specifically in the 3.4 phase, is associated with drought in the central Caribbean (Cuba, Hispaniola, Puerto Rico, and Jamaica) and an increase in the intensity of hurricanes in the region (Chen and Taylor 2002). The positive phase of the NAO generates a drier atmosphere in North Africa, thereby creating better atmospheric conditions for the formation of cyclonic systems, which reach the Caribbean region more frequently (Jury and Enfield 2010, Giannini et al. 2001) due to the trade winds. All these things have had a great effect on increasing the level of Lake Enriquillo and consequently affecting the physical and chemical parameters of the lake water.

One of these parameters, namely the salinity gradient of Lake Enriquillo, increases eastward due to the behavior of the trade winds in the area. This suggests that rainfall conditions in the past were very similar to those of the present and confirms that the connection to the sea on the east side of Lake 
Enriquillo formed later (Buck et al. 2005 and De la Fuente 1976). A historical review shows a gap in information in the fifteenth through eighteenth centuries. Observations are available from the 1900s onwards, when the lake levels reached $30 \mathrm{~m}$ BSL. This suggests that during the interval of the information gap, an accelerated erosion process dragged vast deposits of material, causing the river to lose its channel, and hauled immense amounts of sediment that contributed to the increase in the level of the Laguna de Cabral and therefore Lake Enriquillo. Subsequent evaporation processes then reduced the lake water level to approximately $40 \mathrm{~m}$ BSL. A decrease in precipitation in the LEB area promoted accelerated evaporation in the watershed, where the water balance is in deficit throughout the year (Díaz et al. 2001). Currently, freshwater springs discharge water from the surrounding rocks into the lake at various locations along its periphery. The salinity of Lake Enriquillo varies according to annual and seasonal cycles of aridity and humidity that affect the weather. In recent years, measurements of more than $100 \%$ salinity were recorded during periods of low water levels, with lower salinities of $35 \%$ recorded during periods of high water levels at the lake (Buck et al. 2005).

Apart from the effects of these normal climate cycles, Lake Enriquillo has also been affected by a large number of natural disasters in recent years. The region is an important social and environmental area of the DR, but despite this being one of the richest natural environments in the Caribbean, many of the people living in the region around Lake Enriquillo face severe social and economic inequalities. This population is directly affected by the flooding of Lake Enriquillo and Laguna de Cabral, with estimates of 27,046 citizens being impacted. This is equivalent to $22 \%$ of the total population of the municipalities surrounding the Lake and indirectly $80 \%$ of the total population. The most impacted municipalities have been Jimaní (5,855 people), Duvergé (11,395 people), and Cristóbal (3,865 people), and to a lesser extent Neyba (375 people), Poster River (1,015 people), Villa Jaragua (1,750 people), La Descubierta (526 people), and Mella (750 people) (UNDP 2013).

The purpose of this article is to analyze how the increase in size of Lake Enriquillo has economically and socially impacted more than 100,000 people along the Dominican-Haitian border. In addition, changes in the physicochemical parameters of the water have affected marine life, livestock, and agriculture in general in the region.

\section{Study Area}

The LEB $\left(18^{\circ} 31.7 \mathrm{~N}, 71^{\circ} 42.91 \mathrm{~W}\right)$ was isolated from the Caribbean Sea between 5000 and $2800 \mathrm{BP}$ (before present) by tectonic uplift and fluvial damming by the YSR (Comarazamy et al. 2015). Today, the basin is a closedbasin lake and home to unique flora and fauna. Its sediments also serve as an excellent source of paleo-environmental information (Buck et al. 2005, Mann et al. 1984 and Cuevas et al. 2005).

Lake Enriquillo encloses three islands that are BSL. Isla Cabritos is the most important island in Lake Enriquillo, with an area of $27.6 \mathrm{~km} 2$ and an elongated shape. The other two islands are Barbarita (known locally as "Chiquita"), and 
Islita. During long droughts, the water level of Lake Enriquillo drops, and the islands, particularly Barbarita and Islita, become peninsulas that are accessible by foot. Isla Cabritos has the only hyperxerophytic dry forest that exists BSL in the Caribbean and in any area in Africa or the Americas (Winsor et al., 2012).

Table 1. Locations of sampling stations

\begin{tabular}{|l|cc|}
\hline Stations & Latitude $\left({ }^{\circ} \mathbf{N}\right)$ & Longitude $\left({ }^{\circ} \mathbf{W}\right)$ \\
\hline $\mathrm{S}_{1}$ : Located opposite the park house, & 18.56017 & 71.697 \\
about 500 meters from "Las Zufradas" & & 71.74493 \\
\hline $\mathrm{S}_{2}$ : On Neyba road, heading to La & 18.4922 & 71.70266 \\
Descubierta, on Cabritos Island & & 71.6779 \\
\hline $\mathrm{S}_{3}:$ Borbollones, facing the mine Lime & 18.553 & \\
La Descubierta & & \\
\hline $\mathrm{S}_{4}:$ Between Isla Cabritos and Sierra & 18.467338 & \\
Bahoruco & & \\
\hline
\end{tabular}
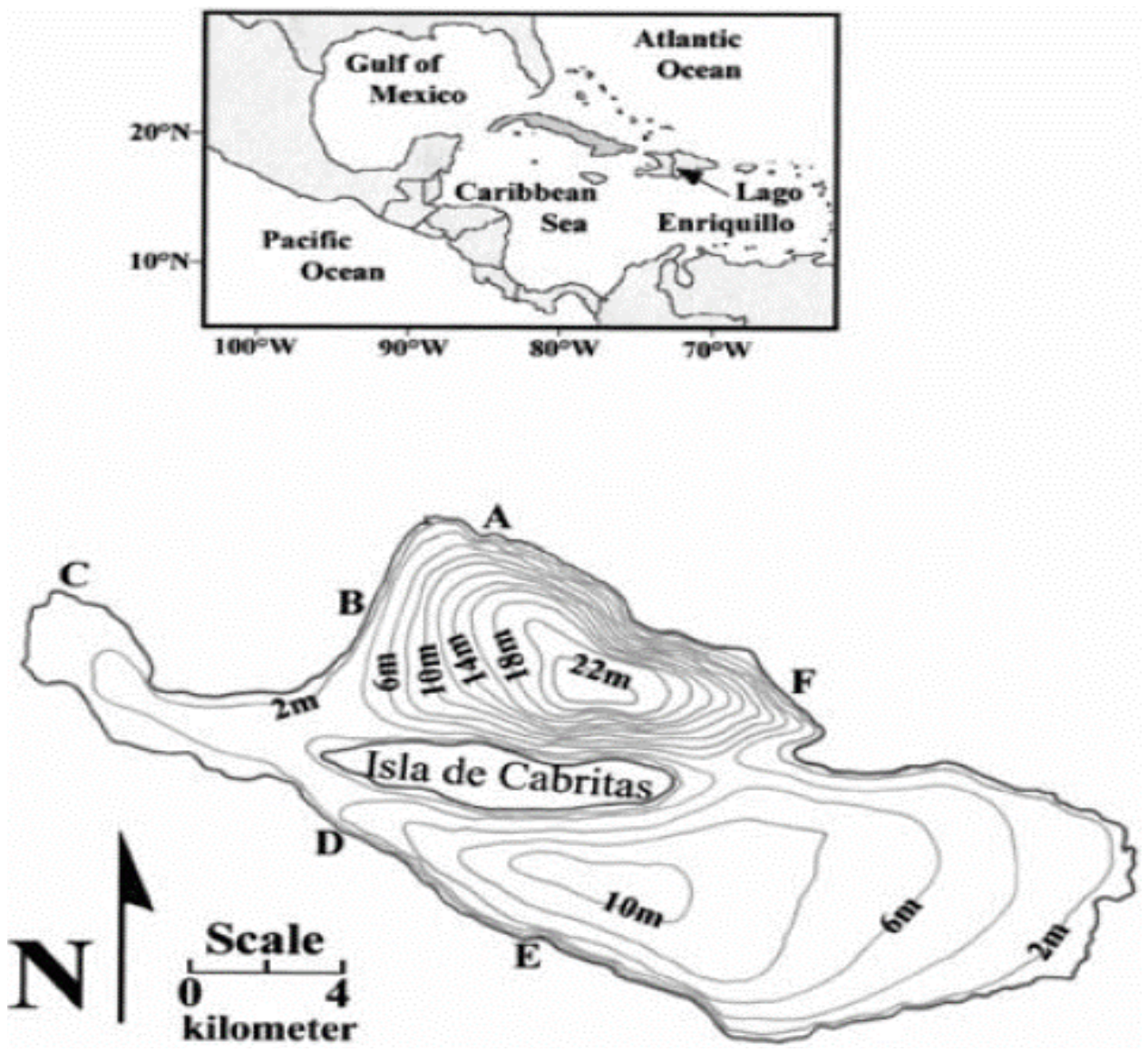

Figure 1. Map showing the location of Lake Enriquillo on the Caribbean island of Hispaniola. Bathymetric map of Lago Enriquillo showing 2-m depth contours (modified from Araguás-Araguás et al., 1993). Letters along the shoreline indicate the approximate location of springs mentioned in the text: (A) La Azufrada, (B) Borbollones, (C) Boca de Cachon, (D) Caoba, (E) La Zurza, and (F) El Guayabal. Source: Buck et al. (2005). 


\section{Methodology}

The hydrochemical characteristics of wetlands are important in interpreting the ecological dynamics of ecosystem components. Several parameters were determined in the water column of Lake Enriquillo, including $\mathrm{pH}$, dissolved oxygen, conductivity, temperature, salinity, and atmospheric pressure. These were registered with the equipment Hydrolab, model 156 ISY. The samples were processed for nitrite, nitrate, phosphate, fecal coliforms, and total coliforms at external laboratories. The results were compared with the permissible limits established by international and national standards for bodies of water for direct use. The measured place were described and physicochemical parameters were determined. The hach water analysis method were used to determine nutrients, using specific kits for water nutrients based on standard colorimetric methods.

Samples were taken from Lake Enriquillo at four stations (Table 1) to analyze the hydrochemical behavior of the wetlands. This behavior is an important component in interpreting the phenomenon of elevated levels in Lake Enriquillo. Measurements of the discharge flow from the wetlands into Lake Enriquillo were taken at different times between 2009 and 2011. Areas where surface water discharged into the lake were also identified during the study. In total, 38 discharge points were manually identified around the lake; however, only 11 were identified as contributing to the water level in Lake Enriquillo. Stream discharge was measured using the wading method, and a reel or current meter was used to determine direct capacities.

The hydrochemistry of the water was evaluated using three chemical parameters: pH, dissolved oxygen, and salinity. Samples were taken in situ and analyzed using the Hydrolab Model 156 ISY. Values for three physical parameters (temperature, evaporation, and precipitation) were determined from historical data (Figure 2) from the most accurate weather station in the LEB (Jimaní). In situ measurements were also taken on each field trip at the same time as samples were taken to determine the values of chemical parameters (Figures 5 and 6).

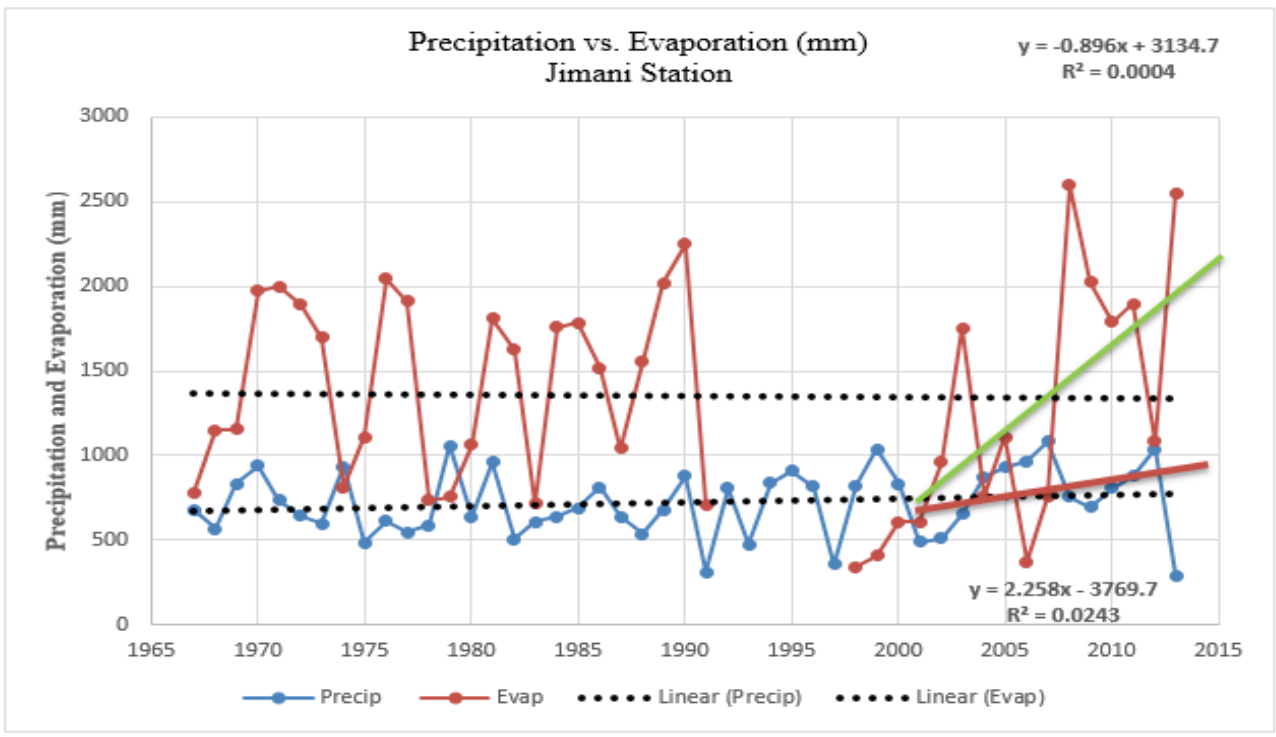

Figure 2. Precipitation versus evaporation at Jimaní station (Lat: $18.29^{\circ} \mathrm{N}$ Lon: $71.51 \mathrm{~W}$ Alt: $31.0 \mathrm{~m}$ ). The complete series shows a slight tendency towards an 
increase in evaporation and a reduction in precipitation in the region; however, from the year 2000, both precipitation (red) and evaporation (green) increase. The rate of increase is much greater for evaporation than for precipitation. Source: National Meteorological Office (ONAMET Spanish acronyms) and Hydraulic Institute Dominican Republic (Spanish acronym INDRHI)

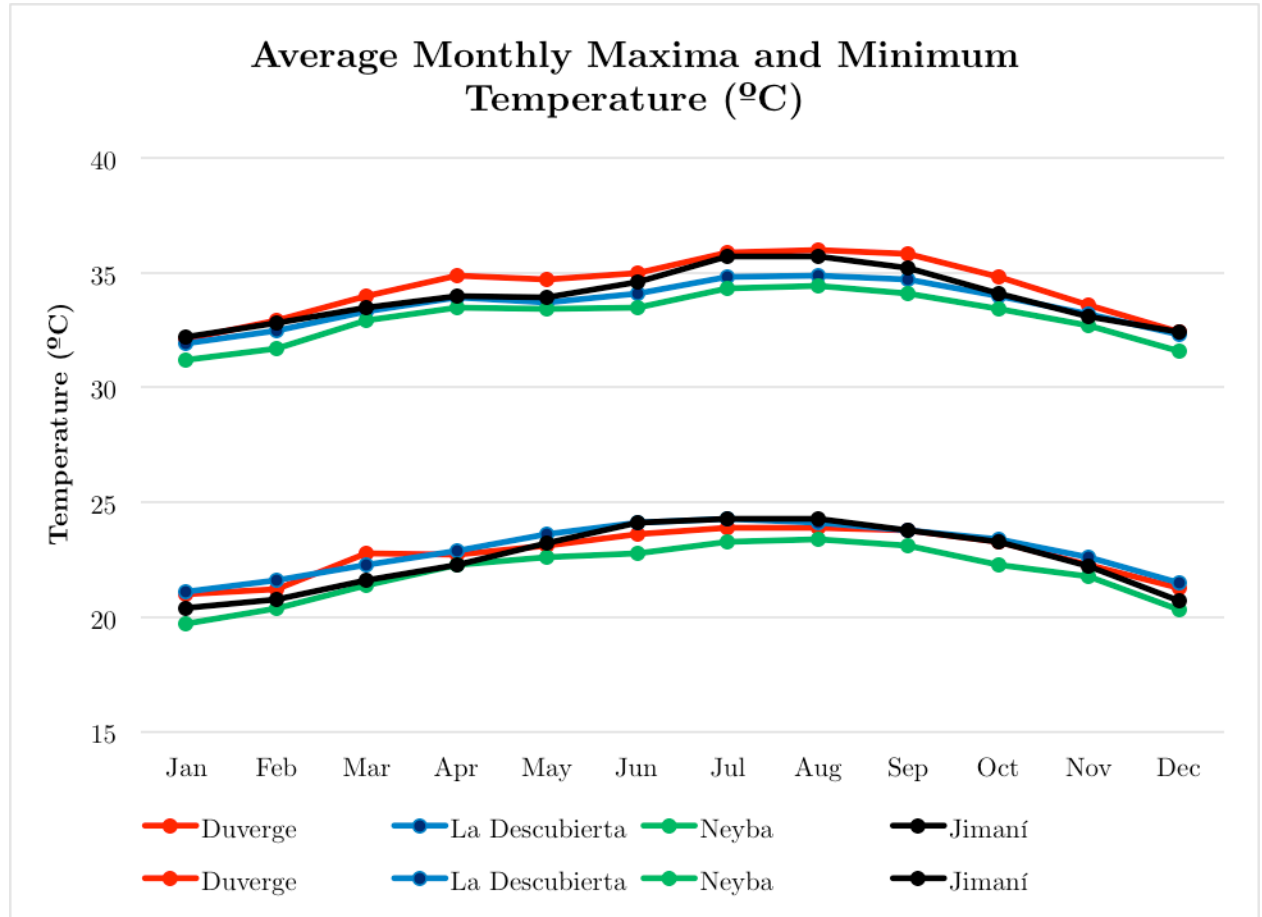

Figure 3. The average monthly temperatures at four stations located in the region of Lake Enriquillo. Data provided by ONAMET.

\section{Hydrochemical Analysis Parameters}

Salinity is an important parameter in aquatic ecosystems, affecting both the biological community and the water density (Jordan and Cassidy 2011 and Records et al. 2014). Salinity influences water circulation and the spatial distribution of other chemical parameters in the water column. The salinity of Lake Enriquillo ranged from 76.81-30.00\% from 1977 to 1996 (Figure 4). In 2002 and 2003, the recorded salinity levels were higher, at $1001.3 \%$ and $101.1 \%$, respectively. In the years 2010 and 2011, the salinity decreased dramatically to $26.1 \%$ and $27.1 \%$, respectively. The $\mathrm{pH}$ of Lake Enriquillo has been very stable over the past 30 years, fluctuating between 7.8 and 8.4. On average, the water temperature ranged between $27.9{ }^{\circ} \mathrm{C}$ and $31.72{ }^{\circ} \mathrm{C}$. The lowest water temperature was in 1977 at $27.9^{\circ} \mathrm{C}$ (Figure 4 ).

Dissolved oxygen is an important regulator of metabolic processes in organisms and in the community as a whole. Its concentrations in natural water depend on the physical, chemical, and biological activities in the water body (Naik et al. 2015, Touhami et al. 2015, Sangeeta and Neha 2015, and Nachshon et al. 2014. During the present study, the highest dissolved oxygen level was observed at sites (Duquela and González 1983 and Hernández and Gewenka 1985) where the oxygen concentration was $0.46-1.7 \mathrm{mg} / \mathrm{l}$. Oxygen concentration levels 
in the water column were at their lowest in the 1970s before they increased to an acceptable amount, ecologically speaking. The lowest values for dissolved oxygen were reported in 2010 and 2011; measurements are lacking for 1979 and 1996. In 2001 and 2002, the value decreased, whereas it increased in 2003 and 2009. Our data show that the dissolved oxygen in the water decreased in 2010 and 2011, with the lowest value of $3.90 \mathrm{mg} / \mathrm{l}$ occurring in 2011. The measurements in the four seasons (Figure 6) showed an average of $8.46 \mathrm{mg} / \mathrm{l}$; however, station S3 showed the highest value at $12.1 \mathrm{mg} / \mathrm{l}$.

Physicochemical Properties of Lake Enriquillo 1977-2001

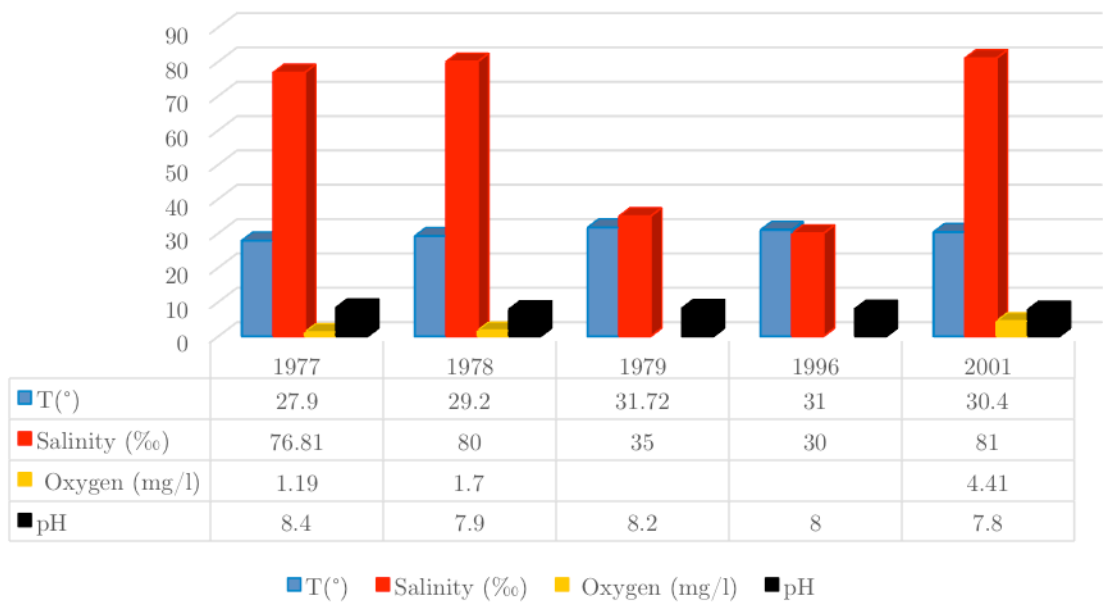

Figure 4. Physicochemical parameters of Lake Enriquillo between 1977 and 1979, 1996, and 2001 (Duquela and González 1983). National Institute of Hydraulic Resources (INDRHI). The 1979 salinity data were taken from Buck et al. (2005).

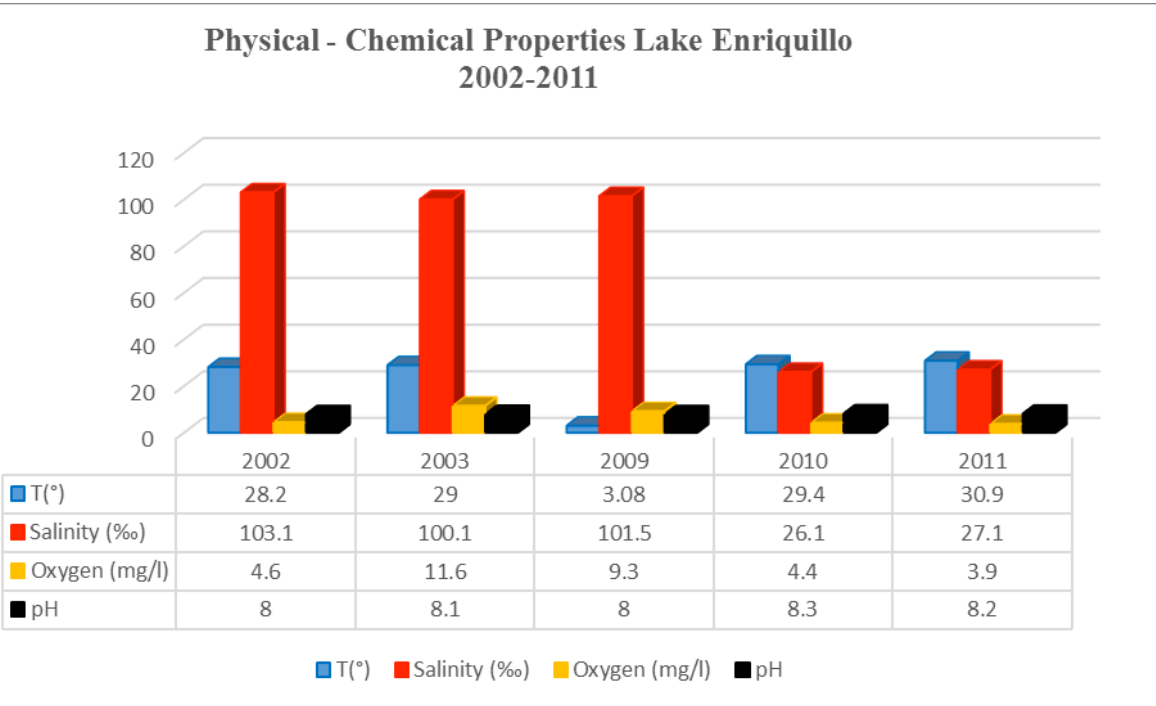

Figure 5. Physicochemical parameters of Lake Enriquillo between 2002 and 2011. Data provided by the Center for Research in Marine Biology (Spanish acronym CIBIMA). 
Physicochemical Properties of Lake Enriquillo 2012

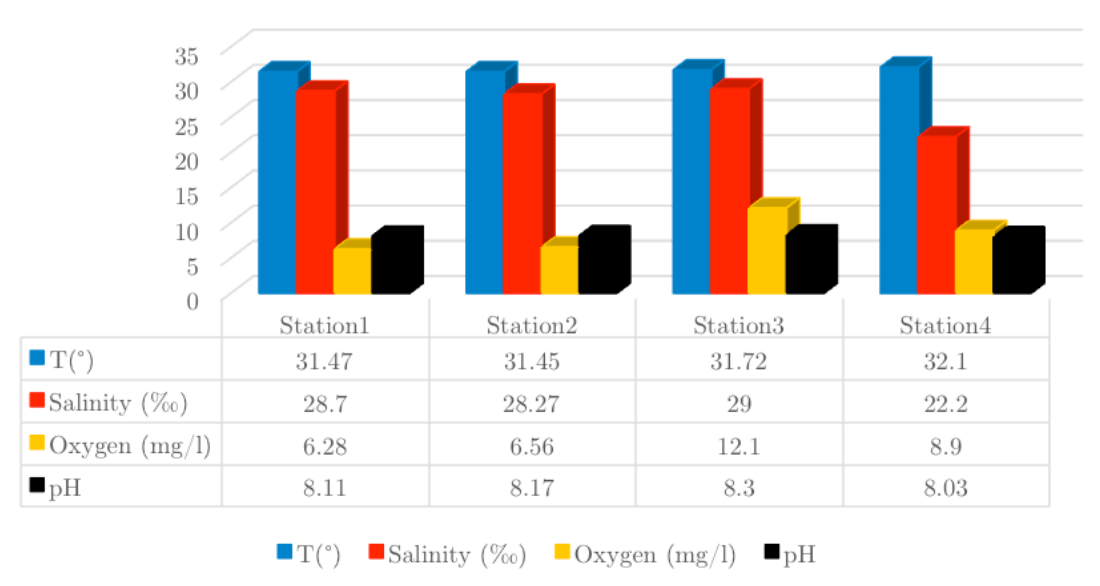

Figure 6. Physicochemical parameters of Lake Enriquillo between 2002 and 2011. Data provided by the Center for Research in Marine Biology (Spanish acronym CIBIMA).

Nutrient concentrations were within the limits permitted by the environmental standards, at $0.5 \mathrm{mg} / \mathrm{l}$ for nitrites and $10 \mathrm{mg} / \mathrm{l}$ for nitrates. The Lake Enriquillo samples ranged from $0.059-0.095 \mathrm{mg} / 1$ for nitrates and 1.275$1.324 \mathrm{mg} / \mathrm{l}$ for nitrites. Note that nitrate levels are normally higher than nitrite levels, but the Lake Enriquillo samples show an opposite relationship.

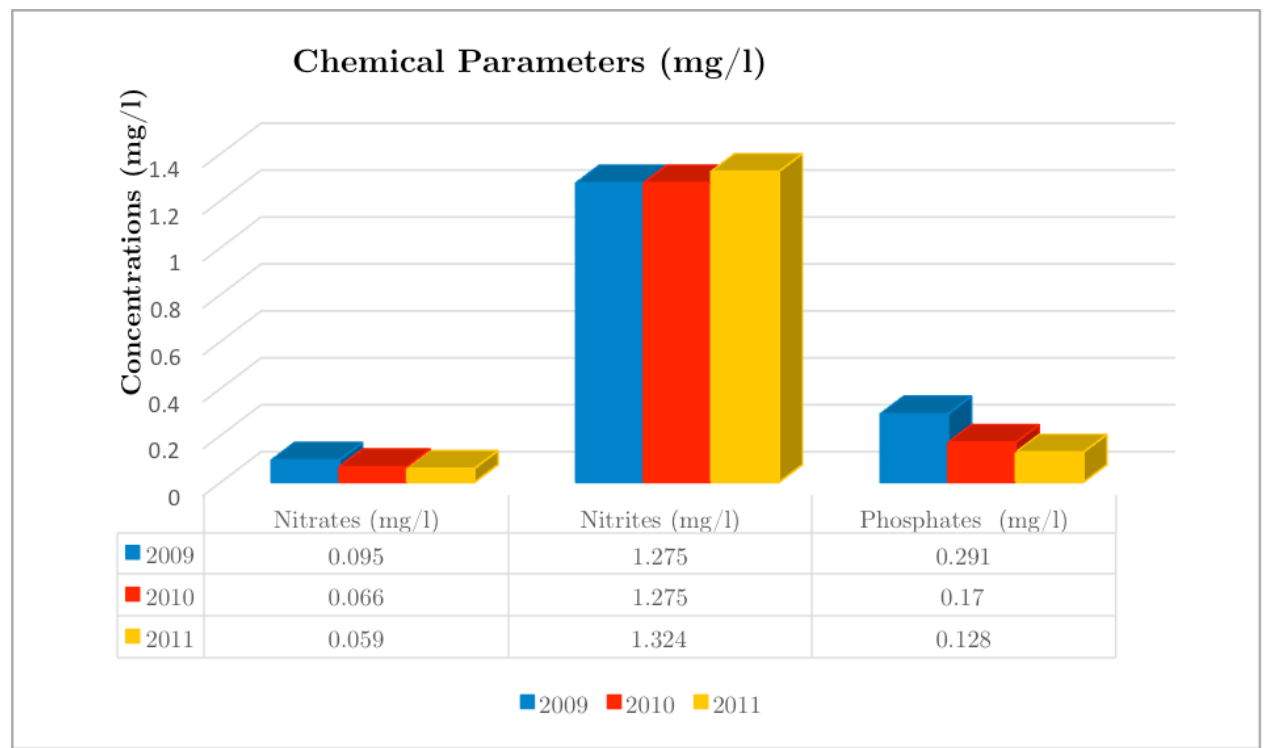

Figure 7. The behavior of chemical water parameters of Lake Enriquillo between2009 and 2011.

\section{Microbiological Analysis Parameters}

The analysis techniques used in this study were those recommended by the Evironmental Protection Agency (EPA) standard method (series 3 tubes) using total coliforms. Escherichia coli and fecal Streptococcus were used as indicators of 
pollution, as described in the publication Volunteer Stream Monitoring: Methods Manual, November 1997. Water samples were delivered to the Universidad Autónoma de Santo Domingo (UASD) laboratories. Nutrients analyzed in this study were nitrite, nitrate, phosphate, and phosphorus. These were determined by spectrophotometry (Hach DR / 2000 software version).

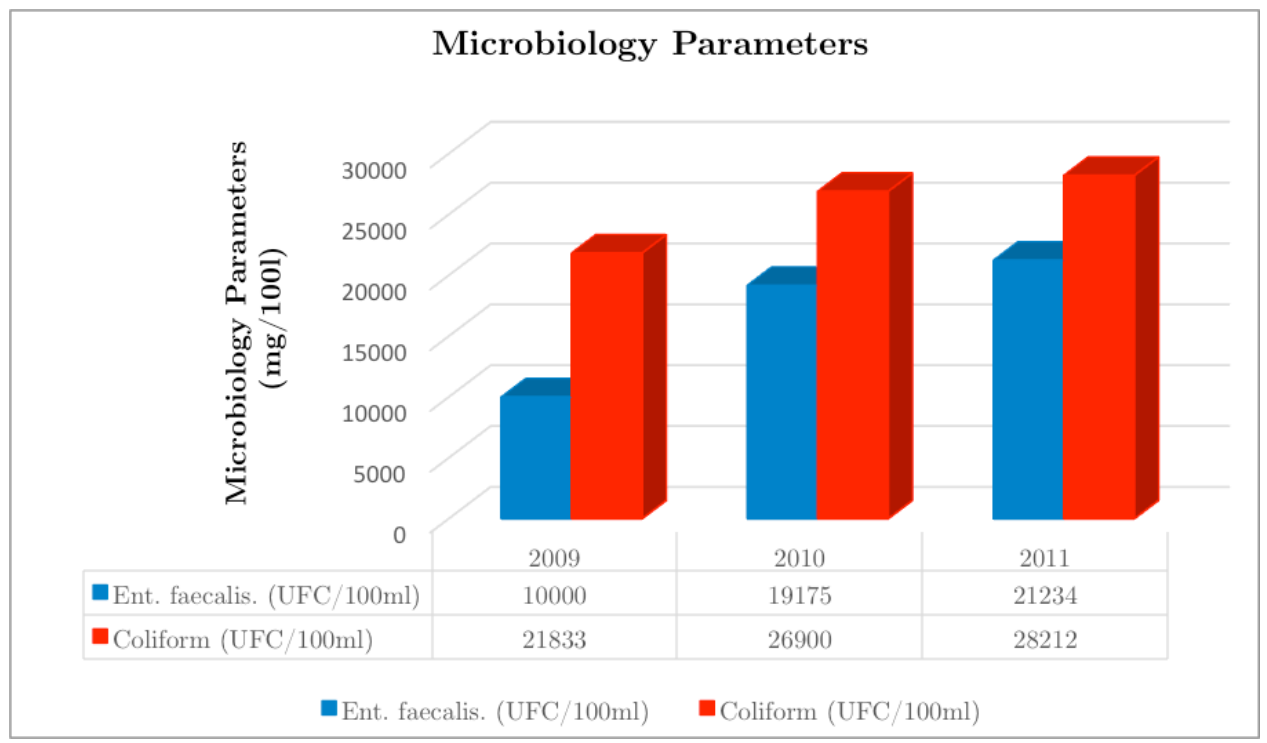

Figure 8. The behavior of the microbiological parameters of the water of Lake Enriquillo between 2009 and 2011.

Nutrients, such as phosphorus, nitrite, and nitrate, allow the production of trophic levels in aquatic ecosystems. The concentrations of nutrients in nitrites and nitrates were within allowable ranges for the environmental standards of the $\mathrm{DR}$; the limit is $10 \mathrm{mg} / \mathrm{l}$. Concentrations of nitrites and nitrates ranged from $0.095-0.066 \mathrm{mg} / \mathrm{l}$. Phosphorus was recorded at $0.291-0.170 \mathrm{ml} / \mathrm{g}$; this parameter was found to be slightly higher than the DR environmental standard of 0.025 to $0.03 \mathrm{mg} / \mathrm{l}$. The slight change in the concentration thereof is probably due to the amount of organic matter in decomposed terrestrial vegetation that was covered by the flooding of the lake and that released nutrients through oxide reduction reactions. Other aspects that can contribute to the contamination levels are dragging, runoff time, prolonged rainfall, and the flooding of cultivated land by the lake, as fertilizers contain nutrients that dissolve in water and thus increase the concentration of nitrites, nitrates, and phosphorus. If this increase is continuous, eutrophication may occur, a process that adversely alters the water quality and affects all aquatic life.

\section{Piezometric Variations}

Historical records are of great importance in understanding the lake's expansion (Bedmar and Araguas 2002, Murillo et al. 2014, Healy and Cook 2012, Sreenivasan 1967 and Smith and Manoylov 2013). The analysis of the variations in water level for Lake Enriquillo showed that the levels have risen in almost all areas of Lake Enriquillo since 1997. This includes the eastern part of the town of Angostura, according to information collected locally. Moreover, the levels have 
risen more than $2 \mathrm{~m}$ in the area of the captive aquifer between Tamayo and Galván.

Assumptions about the effects of the rains were made based on storm events. The average values of the piezometric levels of hurricane seasons from 2007-2008 were evaluated (Romero-Luna and Palteau 2011 and González et al. 2010). From 2008-2009. Some interpretations of the effects of the rains in 2005 were made by taking into account the events related to storms. Analysis of the average values of the piezometric levels during the hurricane seasons from $2007 \neg-2008$ indicated that those levels have increased in the range of $15 \mathrm{~m}$ (maximum) in Puerto Escondido, $11.0 \mathrm{~m}$ in Neyba, and $0.45 \mathrm{~m}$ in Jimaní for the years 2008-2009. The discharge of groundwater during a typical wet year is about $7 \times 108 \mathrm{~m} 3 /$ year and during a typical dry year is $2 \times 108 \mathrm{~m} 3 /$ year. During the last two years, the measured discharge has been higher than the average discharge during typical wet seasons (Méndez et al. 2016).

The hydrogeology of the LEB is associated with the geological origins of the Sierra de Bahoruco and Sierra de Neyba mountain ranges and the discharge basin of the YSR. These wells (aquifers) are located in the following areas:

i. Neyba-Galvan: The wells are mainly conical in shape and are found in phreatic aquifers of high permeability, with source waters from the mountainous areas of the Sierra de Neyba in the north.

ii. South of the town of Galván: The wells are perforations extending for 2-3 kilometers.

iii. The west plain of the YSR (Tamayo-El Jobo): The aquifer is confined and wells are all artesian. The wells are located in the thick alluvial deposits of the YSR (east of the town of Tamayo). These deposits play an important part in recharging the underground system.

iv. Angostura Valley: Located on the eastern boundary of the study area and 3-4 kilometers southeast of the town of Angostura, the wells are all concentrated in a phreatic aquifer.

\section{Average Flows of Surface Waters}

Wetlands, springs, and streams are located along the major tectonic thrust lines that border the Valley of Neyba. Contact is made between both underground and surface bodies of water, which must be taken into account when calculating flows rate region (Méndez-Tejeda et al. 2016 and Comarazamy et al. 2015). The three major streams discharging into Lake Enriquillo are Canal Cristobal, with a flow rate of $0.17058 \mathrm{~m} 3 / \mathrm{s}$; the Naked, with a flow rate of 0.9010 $\mathrm{m} 3 / \mathrm{s}$; and Boca Cachón, with a flow rate of $0.6232 \mathrm{~m} 3 / \mathrm{s}$. These three streams contribute greatly to the water level of Lake Enriquillo (Figure 9). 


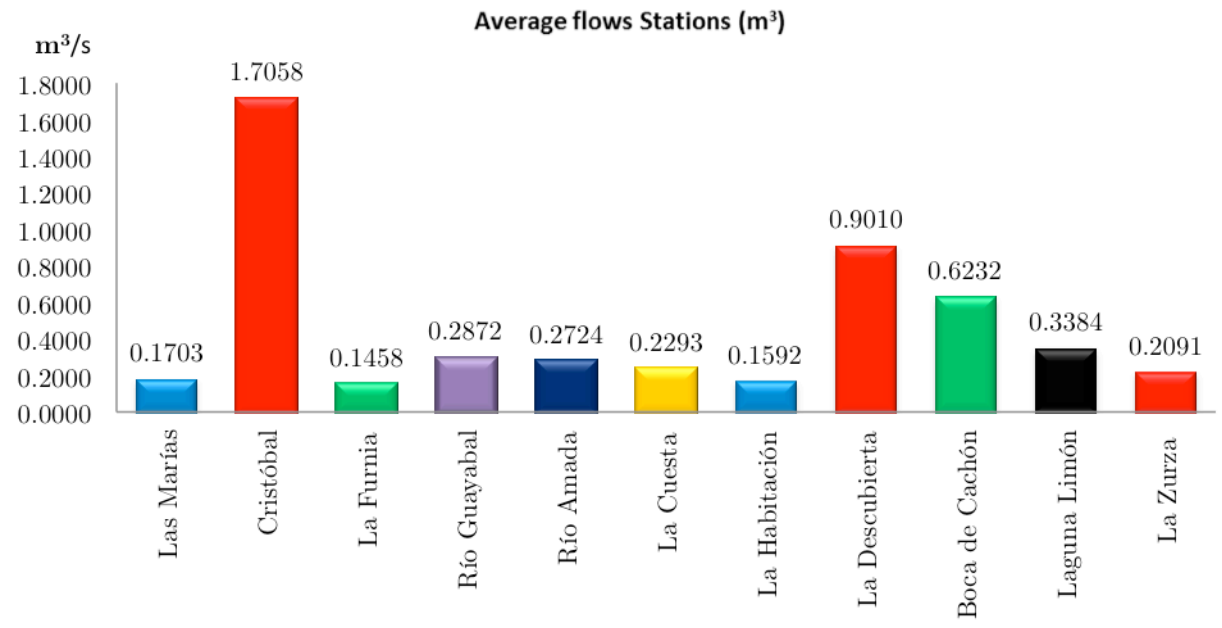

Figure 9. Average flows of 12 major surface water sources that discharge into Lake Enriquillo.

\section{Analysis and Conclusion}

The salinity of Lake Enriquillo was 25\% in 1977 and $31 \%$ in 2001 (Figure 4); however, between 2002 and 2012, the salinity level exceeded 100\% (Figure 5). The dissolved oxygen level was relatively consistent from 1977-2001, but fell to 6-12\% in 2011 and 2012. This decrease coincided with a sharp increase in the water level and a decrease in the salinity to $22 \%$ and $30 \%$, respectively. Temperature and $\mathrm{pH}$ did not vary significantly.

Salinity in the southern basin, at $\sim 2 \%$, was consistently higher than in the northern basin (Buck et al. 2005). From 1977-2001, salinity remained almost constant at 80\%o, except in 1979 (Figure 4). This is due to hurricanes David and Frederick striking the island in August 1979. Measurements showed that Hispaniola experienced $1000.60 \mathrm{~mm}$ of rain as a result, surpassing the annual average of $600 \mathrm{~mm}$.

The water level of Lake Enriquillo increased by $17.2 \mathrm{~m}$ from 2001-2012. This can be largely attributed to the large amounts of rainfall in this period, as recorded by the Caribbean Regulator Climate Center (CRCC) (Méndez-Tejeda et al. 2016). The arrival of fresh water from various tributaries greatly reduced the salinity of Lake Enriquillo. However, the increase in salinity cannot only be attributed to the fresh water provided by the tributaries; instead, it is assumed that the lake received some kind of underground injection.

Variations in oxygen levels greatly affect nutrients and have a consequential effect on the amount of decomposing organic matter. If this amount of decomposing organic matter continues to increase, the eutrophication process might start in Lake Enriquillo. The concentrations of microbiological organisms showed an increasing trend in the three years of data. In the case of fecal Enterococcus, the numbers doubled during the analysis period (2009-2011), while total coliforms increased by approximately $77 \%$ (Figure 8).

The Lake Enriquillo region is rich in underground waters. Hydrogeology is associated with the geology of the Sierra de Bahoruco and Sierra de Neyba mountain ranges and the discharge of the YSR basin. An increase in the level of 
the wells correlates with an increase in the level of the lake, contributing to its expansion.

\section{Acknowledgement}

This article has been produced thanks to the collaboration of Ministerio de Educación, Ciencia y Tecnología (MESCyT) of the Dominican Republic, who financed the project through funds provided by FONDOCYT (2009-2012), NASA Space Grant Consortium, Ministerio de Medio Ambiente y Recursos Naturales. In addition the authors wish to thank Edwin Fernández, for his invaluable help in gathering and organizing data.

\section{References}

Méndez-Tejeda Rafael, Gladys Rosado, Diego V Rivas., Tomás Montilla, Santiago Hernández, Antonio Ortiz, and Francisco Santos, "Climate Variability and Its Effects on the Increased Level of Lake Enriquillo in the Dominican Republic, 2000-2013." Applied Ecology and Environmental Sciences, vol. 4, no. 1. 2016: 26-36. doi: 10.12691/aees-4-1-4.

Comarazamy, D.E.; González, J.E.; Moshary, F.; Plasecki, M. 2015. On the hydrometeorological changes of a tropical water basin in the Caribbean and its sensitivity to midterm changes in regional climate. J. Hydrometeorolog. Available: http://dx.doi.org/10.1175/JHM-D-14-0083.1

Greer, L.; Curran, A.; Patterson, W.; Tibert, N. 2006. The rise and demise of a Holocene coral reef complex, Dominican Republic: The Coral Climate Connection University of Mary Washington 2006. 19th Annual Keck Available: http://keckgeology.org/files/pdf/symvol/19th/domincanrep/greer.pdf

Duquela. J.; González A.; García R. 1983. Hidrometeorología del Lago Enriquillo y emergimiento de la Isla Cabritos. Thesis. Universidad Central del Este (UCE).

Buck, D.G.; Brenner, M.; Hodell, D.A.; Curits, J.H.; Martin, J.B.; Pagani, M. 2005. Physical and chemical properties of hypersaline Lago Enriquillo, Dominican Republic. Verh. Internat. Verein. $\begin{array}{llll}\text { Theor. } & \text { Angew. } & \text { Limnol., } & \text { 725-731. }\end{array}$ http://people.earth.yale.edu/sites/default/files/files/Pagani/4_2005\%20Buck\%20et\%20al.pdf

Chen, A. A.; Taylor, M.A. 2002. Investigating the link between early season Caribbean rainfall and the El Niño+ 1 year. Int. J. Climatol. 22, 87-106. DOI: 10.1002/joc.711

Jury, M.; Enfield, D. 2010. Environmental patterns associated with active and inactive Caribbean hurricane seasons. J. Climate, Apr. 10, 2146-2160. DOI: 10.1175/2009JCLI3201.1

Giannini, A.; Cane, M.A.; Kushnir, Y. 2001. Interdecadal changes in the ENSO teleconnection to the Caribbean Region and the North Atlantic oscillation. American Meteorological Society. J. Climate, 14, 2867-2879. DOI: http://dx.doi.org/10.1175/15200442(2001)014<2867:ICITET>2.0.CO;2

De la Fuente G. Santíago. Geografía Dominicana. 1976. Editora Colegial Quisqueyana, p.100- 112.

Díaz del Holmo, F.; Cámara Artiga, R.; Baena Escudero, R. M.; Ramón B.J. 2001. Informe preliminar del Estudio Eco dinámico del Parque Nacional Lago Enriquillo. p. 69. Agencia Española de Cooperación Internacional. Programa de cooperación Científica con IBEROAMERICA Available: doi:10.1191/095968399669724431

Mann, P.; Taylor, F.W.; Burke, K.; Kulstad, R. 1984. Subaerially exposed Holocene coral reef, Enriquillo Valley, Dominican Republic. Geol. Soc. Am. Bull., 95, 1084-1092.

Medley, P.; Tibert, E.N.; Patterson, W.P.; Curran, A.H.; Greer, L.; Colin, J-P. 2007. Paleosalinity history of middle Holocene lagoon and lacustrine deposits in the Enriquillo Valley, Dominican Republic based on pore morphometrics and isotope geochemistry of Ostracoda. Micropaleontology, 53, 409-419

Cuevas Miranda, D., C. E. Sherman, W. Ramirez, V. Diaz, and D. K. Hubbard, 2005, Development of the Mid-Holocene Cañada Honda fossil reef, Dominican Republic: Preliminary results and implications to modern trends of reef degradation in high sedimentation environments: Transactions 17th Caribbean Geological Conference, p. 27-36. 
Winsor, K., Curran H.A., Greer, L. and Glumac, D. 2012. Unusual Holocene serpulid-tufa biotherms, Enriquillo Valley Dominican Republic. Morphologies and paleoenvironmental implications. Palaios27:693-706 DOI: 10.2110/palo.2011.p11-118r

Jordan, P. and Cassidy, R.: 2011. Technical Note: Assessing a 24/7 solution for monitoring water quality loads in small river catchments, Hydrol. Earth Syst. Sci., 15, 3093-3100, doi:10.5194/hess-15-3093-2011.

Records, R. M., Arabi, M., Fassnacht, S. R., Duffy, W. G., Ahmadi, M., and Hegewisch, K. C 2014.: Climate change and wetland loss impacts on a western river's water quality, Hydrol. Earth Syst. Sci., 18, 4509-4527, doi:10.5194/hess-18-4509-2014.

Naik, G.; Rashid, M.; Balkhi, M.H. 2015. Changes in Physico-chemical Parameters at different Sites of Manasbal Lake of Kashmir, India. Fish Aquac J 6: 148. Available: doi:10.4172/21503508.1000148

Touhami, I.; Andreu, J.M.; Chirio, E.; Sánchez, J.R.; Bosch, P.A.; Martínez-Santos, M.H.; Bellot J. 2014. Comparative performance of soil water balance models in computing semi-arid aquifer recharge. Hydrological Sciences Journal. Volume 59, Issue 1, pp. 193-203. Available: doi:10.1080/02626667.2013.802094

Sangeeta, P.; Neha, P. 2015. Monitoring of Seasonal Variation in Physicochemical Water Parameters in Nalasopara Region. J Ecosys Ecograph 5:156. Available: doi:10.4172/2157-7625.1000156

Nachshon, U.; Ireson, A.; van der Kamp, G.; Davies, S.R.; Wheater H.S. 2014. Impacts of climate variability on wetland salinization in the North American prairies. Wheater. Hydrol. Earth Syst. Sci., 18, 1251-1263. Available: www.hydrol-earth-syst-sci.net/18/1251/2014/ doi:10.5194/hess-18-1251-2014

Hernández, C.; Gewenka, J. 1985. Contribuciones para un nuevo concepto de conservación en el área del Lago Enriquillo. Informe interno del viceministerio de Áreas Protegidas, del Ministerio de Medioambiente y Recursos Naturales.

Bedmar, A.; Araguas, L. 2002. Detection and the Prevention of Leaks from Dams. CRC Press, Jan 1, 2002 - 436 pages. ISBN 9058093557

Murillo, J. M. 2014. Hydrodynamic analysis of the artificial recharge of aquifers during the planning stage Results obtained in the Quaternary aquifer in the Valley of the Guadalquivir (Spain). $\begin{array}{lllll}\text { Boletin Geológico } & \text { y } & \text { Minero, } & \text { 125(2), }\end{array}$ http://www.igme.es/Boletin/2014/125_2/12_Articulo\%209.pdf

Healy, R.W. \& Cook, P.G. Hydrogeology Journal (2002) 10: 91. doi:10.1007/s10040-001-0178-0

Sreenivasan, A. 1967. Application of limnological and primary productivity studies in fish culture. F.A.O.F.sh Report. pp. 44: 101-103. DOI: 10.4172/2150-3508.1000148

Smith, M.E.; Manoylov, K.M. 2013. Changes in Diatom Biodiversity in Lake Sinclair. Journal of Water Resource and Protection, 5, 732-742 Available: http://dx.doi.org/10.4236/jwarp.2013.57074. Published Online July 2013 (http://www.scirp.org/journal/jwarp).

Romero-Luna, E.J.; Poteau, D. 2011. Water Level Fluctuations of Lake Enriquillo and Lake Saumatre in Response to Environmental Changes; M.Eng. thesis of Engineering Project Presented to the Faculty of the Graduate School of Cornell University: Ithaca, NY, USA. https://ecommons.cornell.edu/handle/1813/23555

González, J., Lin, L., Bouton, G., Walker, K., and Molina A. 2010. Growth of Lago Enriquillo. Final Report. Department of Environmental Engineering, Senior Design Project. The City College of New York. 140th Street, New York NY 10031. http://hispaniola-lakes.ccny.cuny.edu/wpcontent/uploads/2013/08/FINAL-REPORT-08_03_10.pdf 